\title{
INTERNALISASI NILAI-NILAI IMAN DAN TAQWA DALAM PEMBENTUKAN KEPRIBADIAN MELALUI KEGIATAN INTRAKURIKULER
}

\author{
Ahmad Khomaini Syafeie \\ Institut Agama Islam Negeri Syekh Nurjati Cirebon \\ syafeieahmad@yahoo.com
}

\begin{abstract}
ABSTRAK
Internalisasi nilai-nilai iman dan taqwa merupakan proses yang dialami seseorang alam menerima dan menjadikan bagian milik dirinya ntuk menanamkan makna yang tersirat dari agama, sebagai wahyu Allah SWT, agar tercapai pemantapan kepribadian. Penelitian ini dilaksanakan di SMA Islam Al Azhar 5 Kota Cirebon dengan menyertakan guru sebagai subyek penelitian. Untuk menghindari kesalahfahaman masalah penelitian ini, penulis hanya mengidentifikasi masalah penelitian pada variable bagaimana teknik yg digunakan guru dan kendalanya dalam menginternalisasikan nilai iman dan taqwa melalui kegiatan intrakurukuler. Penelitian ini menggunakan metode metode deskriptif analitis dengan pendekatan kuantitatif. Sedangkan untuk mengumpulkan data yang diperlukan dengan menggunakan teknik wawancara, observasi partisipatif, studi dokumentasi dan angket. Hasil penelitian dapat disimpulkan bahwa, (1) berdoa dan sebelum belajar adalah $75 \%$ dengan kategori bagus; (2) membaca Alquran 15 menit sebelum belajar adalah 81,7\% dengan kategori bagus sekali; (3) mengintegrasikan muatan imtaq pada mata pelajaran adalah $90 \%$ dengan kategori bagus sekali.
\end{abstract}

Kata kunci: internalisasi, nilai iman dan taqwa, intrakurikuler

\section{ABSTRACT}

Internalization of the values of iman and taqwa is a process experienced by someone in accepting and making parts of ownership to plant sense textually from religion, as revelation of Allah to achieve his personality steadily. This ressearch conducted in Al Azhar Senior high School 5 in Cirebon City by using teachers as research subject. To avoid misunderstanding of the reserach problem, the writer just identifies research problems on the variables such as tehnique used by teachers and his obstacles in internalizing the values of iman and taqwa through intracurricular activities. This research done by using analytic-descriptive method with quantitative approach. Meanwhile the steps to collect the data nedded in this research by using the technique of interview, participative observation, documentation study and questionaire. The result of this research can be inferred that, (1) praying before and after learning process is $75 \%$ in good category; (2) reciting Alquran 15 minutes in the first period before learning is $81,7 \%$ in excellent category and (3) bringing learning subjects into iman and taqwa loading is $90 \%$ in excellent category.

Keywords: internalization, iman and taqwa value, personality, intracurricular

A. Latar Belakang

Islam sebagai suatu agama yang mutlak kebenarannya harus menjadi pedoman hidup dan kehidupan bagi setiap umat Islam, sehingga akan mendapatkan kebahagiaan 
hidup di dunia dan di akhirat. Konsekuensi Islam sebagai agama yang dianut, menuntut harus adanya upaya pewarisan nilai-nilai ajaran Islam, iman dan taqwa (imtaq), dari satu generasi kepada generasi berikutnya, sehingga tetap terpelihara sebagai pedoman hidup. Adapun sarana yang paling tepat adalah dengan internalisasi nilai-nilai tersebut.

Sekolah merupakan wahana internalisasi nilai-nilai imtaq bagi pelajar muslim, setelah lingkungan keluarga dan masyarakat, memberikan kontribusi yang sangat berarti dalam pembentukan kepribadian seseorang. Namun bagaimana upaya-upaya pelaksanaan internalisasi nilai-nilai imtaq bagi pelajar muslim di sekolah, terutama di SMA yang siswanya berusia remaja. Menurut Zakiyah Darazat bahwa masa remaja atau adolosence (13 - 21 tahun) lazim dikenal sebagai masa percobaan. ${ }^{1}$

Hasil penelitian tentang internalisasi nilai-nilai agama (Islam) sampai dengan saat ini sudah cukup banyak dengan beragam obyek, materi dan tempat peneltian sesuai dengan interest dan latar belakang keilmuan para peneliti, seperti judul penelitian sebagai berikut:

1. Pengaruh Bahan Ajar Konsep Dasar Matematika Berbasis Internalisasi nilai-Nilai Islam terhadap Sikap Religius ${ }^{2}$

2. Internalisasi Pendidikan Agama Islam pada Tradisi Meron ${ }^{3}$

3. Internalisasi Religuitas pada Anak dalam Keluarga ${ }^{4}$

Dari kondisi di atas penulis terpanggil untuk mengadakan penelitian dengan fokus yang berbeda yakni mengenai bagaimana usaha guru dalam proses internalisasi nilai-nilai agama (Islam) bagi pembentukan kepribadian siswa SMA (usia remaja).

Dengan keterbatasan yang dimiliki peneliti dengan permasalahan yang kompleks ini, penulis mengadakan penelitian dengan memfokuskan pada usaha guru dalam menginternalisasikan nilai-nilai iman dan taqwa (imtaq) bagi pembentukan kepribadian siswa di SMA ISLAM AL AZHAR 5 Kota Cirebon melalui kegiatan intrakurikuler.

\footnotetext{
${ }^{1}$ Zakiyah Darazat, Pendidikan Agama dalam Pembinaan Mental, ( Jakarta :Bulan Bintang. 1970), 72

${ }^{2}$ Nuhyal Ulia; Yunita Sari;Mohamad Hariyono, Jurnal Studi Guru dan Pembelajaran, Vol 3, Iss 1, Pp 1-10 (2020); Universitas Cokroaminoto Palopo, 2020

${ }^{3}$ Maisyanah Maisyanah;Lilis Inayati, Edukasia:Jurnal Penelitian Pendidikan Islam, Vol 13, Iss 2 (2019), STAIN Kudus, 2019

${ }^{4}$ Musa Alfadhil, Jurnal Mudarrisuna: Media Kajian Pendidikan Agama Islam, Vol 9, Iss 1, Pp 26-35,(2019), UIN Ar Raniri, 2019
} 
B. Tinjauan Teori

1. Pengertian dan Proses Internalisasi

Dali Gulo (1982: 128) mengemukakan bahwa pengertian internalisasi adalah penyatuan ke dalam pikiran atau kepribadian; pembuatan nilai-nilai; patokan-patokan; ide-ide atau praktek-praktek dari orang lain menjadi bagian dari diri sendiri. ${ }^{5}$

Loewald berkomentar bahwa dia menggunakan istilah internalisasi di sini sebagai istilah umum untuk proses transformasi tertentu terhadap hubungan dan interaksi ke dalam perangkat psikis individu lain (inner relationship and interaction). ${ }^{6}$

Sedangkan menurut Kamus Besar Bahasa Indonesia internalisasi adalah penghayatan terhadap suatu ajaran, doktrin, atau nilai sehingga merupakan keyakinan dan kesadaran akan kebenaran doktrin atau nilai yang diwujudkan dalam sikap dan prilaku. $^{7}$

Dari ungkapan para ahli di atas tentang definisi internalisasi, maka dapat disimpulkan bahwa internalisasi adalah suatu proses transformasi nilai-nilai yang dimiliki seseorang kepada orang lain sehingga orang tersebut memiliki nilai-nilai tersebut sebagai hasil dari proses internalisasi.

Dalam prosesnya internalisasi ini jelaslah bahwa lingkungan merupakan faktor utama bagi terbentuknya internalisasi. Artinya proses internalisasi ini tidak akan terbentuk tanpa adanya lingkungan yang sangat mempengaruhi dalam kehidupan. Sebagaimana telah diketahui bahwa dalam kehidupan sehari-hari manusia tidak akan bisa lepas dari hubungan antara yang satu dengan yang lainnya. Manusia berusaha menyesuaikan diri dengan lingkungannya, sehingga kepribadian individu, kecakapankecakapan individu beserta ciri-ciri kegiatannya baru akan menjadi kepribadian (terinternalisasi dalam diri seseorang) apabila keseluruhan psycho-physic berhubungan dengan lingkungannya. ${ }^{8}$

${ }^{5}$ Dali Gulo, Kamus Pschology.(Bandung :Tonis. 1982), 128

${ }^{6}$ Loewald, Internalization, Separation, Mourning and the Superego ; Pschoanalitic Quarterly.journal of the American Psychoanalytic Association. 1962, 489

${ }^{7}$ Depdiknas, Kamus Besar Bahasa Indonesia. (Jakarta: Balai Pustaka. 2001), 439

${ }^{8}$ Abu Ahmadi, Psikologi Sosial .(Jakarta:Cipta Rineka,Cetakan I.1991),53 
Dalam hal tersebut di atas, Abu Ahmadi menjelaskan bahwa para ahli psikologi sosial meninjau tentang bagaimana pengaruh lingkungan terhadap terhadap sikap perkembangan seseorang, apakah pengaruh tersebut mutlak atau tidak. ${ }^{9}$

Tahapan teknik internalisasi menurut Muhaimin ada empat yaitu; (1) tahap transformasi nilai, komunikasi satu arah, guru yang aktif; (2) tahap transaksi nilai, komunikasi dua arah, guru dan siswa sama-sama aktif; (3) tahap transinternalisasi nilai, komunikasi dua kepribadian yang masing-masing terlibat secara aktif. ${ }^{10}$

Proses transinternalisasi mulai dari menyimak, menanggapi, memberi nilai, mengorganisasikan nilai dan karakteristik nilai yakni membiasakan nilai-nilai yang benar yang diyakini, dan yang terorganisir dalam laku pribadinya sehingga nilai tersebut sudah menjadi watak (kepribadiannya), yang tidak dapat dipisahkan lagi dari kehidupannya. Nilai yang sudah mempribadiinilah yang dalam Islamdisebut dengan keimanan yang istikomah,yang sulit tergoyahkan oleh situasi apapun. ${ }^{11}$

2. Konsep Nilai-nilai Iman dan Taqwa

a. Hakikat Nilai

Hakikat adalah intisari, dasar, kenyataan yang sebenarnya (Depdiknas, 1996:335).

Jack R. Fraenkel menyatakan nilai (value) adalah suatu ide atau konsep tentang segala sesuatu yang berharga dalam kehidupan. Sebagamana dinyatakan:

"A value is an idea-a concept-about what someone thins is important in life. When a person values something, he or she seems it wortywhile-worth having, worth doing, or worth trying to obtain. The study of values usually is divided into the areas of aesthetic and ethics. Aesthetics refers to the study and justification of human beings consider beautiful-what they enjoy. Ethics refers to the study and ustification of conduct-how people behave. At the base study of ethics is the question of morals-the reflective consideration of what is right and wrong". 12

\footnotetext{
${ }^{9}$ Psikologi Sosial, 55-56

${ }^{10}$ Muhaimin, Paradigma Pendidikan Islam, (Bandung:PT. Remaja Rosdakarya, 2001), 178

${ }^{11}$ Paradigma Pendidikan Islam, 179

${ }^{12}$ Fraenkel, How to Teach about Values: An analytic Approach. (Bey Jersey: Printice Hall Inc. Englewood Cliff. 1977), 6-7
} 
Menurut kamus besar bahasa Indonesia dalam entri nilai memiliki berbagai makna dari kata nilai tersebut, yakni: (1) harga (dalam arti taksiran harga); (2) harga uang (dibandingkan dengan harga uang yang lain); (3) angka kepandaian; (4) banyak sedikitnya isi, kadar, mutu; (5) sifat-sifat (hal-hal) yang penting atau berguna bagi kemanusiaan; dan (6) sesuatu yang menyempurnakan manusia dengan hakikatnya; etika dan ... berhubungan erat. Nilai etik nilai bagi manusia sebagai pribadi yang utuh, misalnya kejujuran, nilai yang berhubungan dengan akhlaq; nilai yang berkaitan dengan benar dan salah yang dianut oleh golongan dan masyarakat. ${ }^{13}$

Karena itu, untuk kebutuhan pengertian nilai yang lebih sederhana namun mencakup keseluruhan aspek yang terkandung dalam definisi di atas kita ambil definisi baru yang dikemukakan oleh Rohmat Mulyana yaitu nilai adalah rujukan dan keyakinan dalam menentukan pilihan. Definisi ini dapat mewakili definisi di atas, walaupun ciriciri spesifik seperti norma, keyakinan, cara, tujuan, sifat, dan ciri-ciri lain tidak diungkapkan secara eksplisit. ${ }^{14}$

\section{b. Hakikat Iman}

Menurut Abu Hayan dalam tafsir al-Bahr al Muhith bahwa iman dari segi bahasa diartikan sebagai pembenaran hati. Iman terambil dari kata amn atau amanah yang berarti "keamanan/ketentraman", sebagai antonim dari "khawatir atau takut". Dari akar kata ini (amn) terbentuk sekian banyak kosa kata yang walaupun mempunyai arti yang berbeda-beda namun pada akhirnya kesemuannya bermuara kepada makna "tidak mengkhawatirkan/aman dan tentram". ${ }^{15}$

Ada dua pengertian iman, pertama, iman sebagai institusi, yaitu iman yang merupakan bagian (paling pokok) daripada agama sendiri. Itulah sebagai bentuk kepercayaan tertinggi dalam arti sesuatu yang diakui sebagai benar, seperti rukun iman yang enam dalam agama Islam. Kedua, dalam arti sikap jiwa. Iman yang merupakan anak kunci pembuka pintu pustaka kebenaran tersebut ialah iman dalam arti yang kedua ini, yaitu sikap jiwa sami'na wa atha'na: mendengar dan mengatakan "ya"! serta

\footnotetext{
${ }^{13}$ Kamus Besar Bahasa Indonesia, 783

${ }^{14}$ Rohmat Mulyana, Mengartikulasikan Pendidikan Nilai,(Bandung:Alfabeta,2004), 11

${ }^{15}$ Abu Hayan, Tafsir al Bahr al Muhith, Jilid I.( Mesir : Dar al Fikr. 1978), 38
} 
menaati firman Ilahi dengan penuh kedirian, memusatkan segala pengabdian hanya kepada-Nya, menyerahkan diri, hidup dan mati semata-mata kepada-Nya. ${ }^{16}$

Iman merupakan bawaan (al-munazzalah/given) dan merupakan potensi manusia. Sebagai bawaan, iman baru merupkan 'ilm (pengertian/pengetahuan) tentang Allah pada tingkat awan. Karena itu setiap manusia mempunyai kepercayaan terhadap atau memiliki pengetahuan tentang Tuhan (Allah), bahkan iblis atau syaithan pun percaya terhadap adanya Allah. ${ }^{17}$

Dari situ dapat dipahami, bahwa iman ternyata tidak sekedar percaya kepada Allah, tetapi mencakup pula pengertian yang benar tentang siapa Allah yang kita percayai itu dan bagaimana kita bersikap kepada-Nya serta kepada obyek-obyek selain Dia. $^{18}$

Ahmad Mudjab Mahalli mengatakan bahwa seorang mukmin paripurna adalah seorang yang sempurna keimanannya baik lahir maupun batin, dekat dengan Allah dan sayang terhadap sesama. ${ }^{19}$

\section{c. Hakikat Taqwa}

Di dalam Munjid Fi al Lughah wa al-A'lam (1986:115) Luis Ma'luf mengatakan bahwa tercatat kata "taqwa" terulang dalam Alquran lebih kurang sebanyak 17 kali, berasal dari akar kata "waqaa-yaqiy-wiqayah", yang berarti menjaga, menghindari, menjauhi, takut, berhati-hati. ${ }^{20}$

Muhammad Quraish Shihab di dalam tafsir Al-Amanah menjelaskan bahwa kalau kita meneliti ayat-ayat Alquran, ternyata perintah taqwa itu terulang-ulang sebanyak 79 kali, sedangkan obyek dari taqwa ialah: Allah sebanyak 56 kali, neraka 2 kali, hari kemudian 4 kali, fitnah/bencana 1 kali, tanpa obyek 1 kali (namun dipahami dari konteksnya bahwa yang dimaksud adalah Allah). Adapun selebihnya 15 kali obyeknya bervariasi, seperti rabbakum, rabbakum al-ladzi khalaqakum, al-ladzi amaddukum bimaa ta 'lamun, amaddukum bi an 'aamin wa baniin, dan lain-lain. ${ }^{21}$

\footnotetext{
${ }^{16}$ Anshari, Ilmu, Filsafat dan Agama.( Surabaya:PT. Bina Ilmu, 1987),143

${ }^{17}$ Muhaimin.. Wacana Pengembangan Pendidikan Islam. (Surabaya: Pustaka Pelajar. 2003), 150

${ }^{18}$ Islam Doktrin dan Peradaban. (Jakarta:Yayasan Wakaf Paramadina. 1992), 75

${ }^{19}$ Ahmad Mudjab Mahalli, Membangun Pribadi Muslim. (Yogyakarta: Menara kudus. 2002), 47

${ }^{20}$ Luis Ma'luf, Munjid Fi al Lughah wa al-A 'lam.. (Libanon:al Maktabah al Syarqiyah.Beirut. 1986), 115

${ }^{21}$ Muhammad Quraish Shihab Tafsir al-Amanah. (Jakarta:Pustaka Kartini. 1992), 59
} 
Menghindari siksa atau hukuman Allah antara lain dapat ditempuh dengan "Imtitsal al-awamir wa ijtinab al-nawaahi" (menjalankan segala sesuatu yang diperintahkann-Nya dan menjauhi atau menghindari segala sesuatu yang dilarang-Nya). Istilah taqwa sering diartikan demikian. Hal ini dapat terlaksana melalui rasa takut dari siksaan (yaitu Allah). ${ }^{22}$

Taqwa lahir sebagai konsekuensi logis dari keimanan yang kokoh, keimanan yang selalu dipupuk dengan muroqobatullah, merasa takut terhadap murka dan azabNya, dan selalu mengharap limpahan karunia dan maghfirah-Nya. Atau sebagaimana didefinisikan oleh para alim ulama. Taqwa hendaklah Allah tidak melihat kamu berada dalam larangan-larangan-Nya dan tidak kehilangan dalam perintah-perintah-Nya. Sebagaian ulama lain mendefnisikan taqwa dengan mencegah diri dari azab Allah dengan membuat amal shalih dan takut kepada-Nya dikala sepi atau terang. ${ }^{23}$

Cukuplah kiranya, keutamaan dan pengaruh taqwa merupakan sumber segala kebaikan di masyarakat, sebagai satu-satunya cara untuk mencegah kerusakan, kejahatan dan perbuatan dosa. Bahkan, taqwa merupakan pilar utama dalam pembinaan jiwa dan akhlaq seseorang dalam rangka menghadapi fenomena kehidupan. Agar ia bisa membedakan mana yang baik dan mana yang buruk dan agar ia sabar atas segala ujian dan cobaan. Itulah hakikat taqwa dan itulah pengaruhnya yang sangat menentukan dalam pembentukan pribadi dan masyarakat.

\section{d. Kepribadian}

Berbicara tentang kepribadian biasanya menyangkut banyak aspek seperti kedirian, karakter, watak, ego, oknum, self, dan bahkan menyangkut identitas bangsa. ${ }^{24}$ Istilah "kepribadian" sering dijumpai dalam beberapa literatur dengan berbagai ragam makna dan pendekatan. Sebagian psikolog ada yang menyebut kepribadian dengan (1) personality (kepribadian) sendiri, sedangkan ilmu yang membahas personality disebut The Psichology of Personality atau Theory of Personality; (2) Character (watak, perangai) sedangkan ilmu yang mempelajari

\footnotetext{
${ }^{22}$ Wacana Pengembangan Pendidikan Islam, 155

${ }^{23}$ Nasih Ulwan, Tarbiyah Ruhiyah: Petunjuk Praktis Mencapai Derajat Taqwa. (Jakarta:Gema Insani Press.2001), 7

${ }^{24}$ Sukanto, Nafsiologi. (Jakarta :Integsita Proses. 1985), 142
} 
ilmu ini disebut dengan The Psychology of Character atau Characterology; dan (3) type (tipe), sedang ilmu yang membahas tentang tipe disebut dengan Typelogy. (Malik B. Badri, 1986: 68-69) Ketiga istilah tersebut yang tepat digunakan adalah istilah kepribadian. Selain ruang lingkupnya jelas, istilah kepribadian juga mencerminkan konsep keunikan diri seseorang. ${ }^{25}$

Untuk mengantisipasi teori psikologi Barat tersebut Fadhil Al-Djamaly menggambarkan kepribadian muslim sebagai muslim yang berbudaya, yang hidup bersama Allah dalam tingkah laku hidupnya, dan tanpa akhir ketinggiannya. ${ }^{26}$

Dalam memberikan analisanya tentang akhlak yang berhubungan dengan pembentukan kepribadiannya Ramayulis menngutip pendapat Moh. Abdullah Darraz mengemukakan bahwa pendidikan akhlak berfungsi sebagai pemberi nilai-nilai Islam. Dengan adanya nilai-nilai Islam Islam itu dalam diri seseorang atau ummah akan terbentuk pulalah kepribadiannya sebagai kepribadian muslim. Akhlak yang mulia mengandung konotasi pengaturan hubungan yang baik antara hamba dengan Allah, dengan sesamanya dan dengan makhluk lainnya. ${ }^{27}$

Selanjutnya Jalaluddin menjelaskan bahwa pembentukan kepribadian muslim sebagai ummah berjalan seiring. Tujuan utama pembentukan itu adalah untuk merealisasikan diri dan ummah sebagai pengabdi Allah yang setia, yang menjadi dasar dan tujuan yang akan dicapai. ${ }^{28}$

Dari uraian di atas dapat disimpulkan bahwa wujud daripada pribadi muslim adalah taqwa kepada Allah, berbudi pekerti luhur, berkepribadian yang sempurna, memiliki pengetahuan dan wawasan yang luas, serta sehat jasmani dan ruhaninya. Manusia yang taqwa kepada Allah SWT. maksudnya adalah orang yang takut dan cinta kepada Allah, hati-hati dan waspada, menjaga diri dari segala sikap, tindakan dan perbuatan yang tidak dirdloi oleh Allah SWT; melaksanakan segala perintah-Nya

C. Metode Penelitian

Penelitian ini menggunakan metode deskriptif analitis dengan pendekatan kuantitatif. Sedangkan langkah-langkah untuk mengumpulkan data yang diperlukan dalam

\footnotetext{
${ }^{25}$ Malik B. Badri, Dilema Psikolog Muslim, Terjemahan; Siti Zaenab Lukfiati..( Jakarta: Pustaka Firdaus 1986), 68-69

${ }^{26}$ Fadhil Al-Djamaly, Ilmu Pendidikan Islam, Terjemahan;M. Arifin. (Jakarta: Bumi Aksara 1991), 170

${ }^{27}$ Ramayulis, Ilmu Pendidikan Islam. (Jakarta:Kalam Mulia. 2004), 295

${ }^{28}$ Jalaluddin,.Kepribadian Muslim, (Palembang :Diktat. 1964, 10
} 
penelitian ini dengan menggunakan teknik wawancara, observasi partisipatif, studi dokumentasi dan angket.

Untuk mendapatkan data yang dianalisa secara statitik, maka terlebih dahulu merubah data dari kualitatif menjadi kuantutatif dengan memberikan nilai setiap item pada alternatif jawaban. Setelah itu, nilai-nilai dari setiap item dijumlahkan secara keseluruhan, sehingga memperoleh skor dari setiap jawaban masing-masing. Sedangkan untuk mengetahui sejauhmana pelaksanaan internalisasi yaitu mengambil prosentasi yang memakai rumus menurut Wahyudin Syah sbb. :

$\mathrm{F}$

$---\mathrm{X} 100=\ldots \%$

$\mathrm{N}$

Keterangan: $\quad \mathrm{F}=$ Frekwensi jawaban

$$
\begin{aligned}
& \mathrm{N}=\text { Jumlah responden } \\
& \%=\text { hasil }
\end{aligned}
$$

Adapun kriteria yang digunakan untuk menginterpretasikannya sebagai penafsiran data

\begin{tabular}{|c|c|c|}
\hline & $100 \%$ & $=$ seluruhnya \\
\hline 90 & $90 \%$ & $=$ hampir seluruhnya \\
\hline \multirow[t]{2}{*}{51} & $89 \%$ & $=$ sebagian besar \\
\hline & $50 \%$ & $=$ setengahnya \\
\hline 40 & $49 \%$ & $=$ hampir setengahnya \\
\hline 20 & $39 \%$ & $=$ sebagian kecil \\
\hline 1 & $19 \%$ & $=$ sedikit sekali \\
\hline & & $=$ tidak ada sekali ${ }^{29}$ \\
\hline
\end{tabular}
adalah:

${ }^{29}$ Wahyudin Syah, Pengantar Penelitian Ilmiah.( Bandung:Tarsito. 1989), 61 
Setelah diklasifikasikan dengan skala prosentase, maka penulis menggunakan kategori klasifikasi yaitu: baik sekali, baik, cukup, kurang dan kurang sekali. Hal ini mengacu pada pendapat Nasrun Harahap, dkk (1983:97) yaitu sebagai berikut:

$\begin{array}{llllll}\text { A. } & \text { Baik sekali } & - & \text { berkisar antara } 81 & - & 100 \% \\ \text { B. } & \text { Baik } & - & \text { berkisar antara } 61 & - & 80 \% \\ \text { C. } & \text { Cukup } & - & \text { berkisar antara } 41 & - & 60 \% \\ \text { D. } & \text { Kurang } & - & \text { berkisar antara } 21 & - & 40 \% \\ \text { E. Kurang sekali } & - & \text { berkisar antara 0 } & - & 20 \%\end{array}$

D. Temuan dan Pembahasan Penelitian

1. Model kurikulum SMA Islam Al Azhar 5 Kota Cirebon

Model kurikulum SMA Islam Al Azhar 5 kota Cirebon terdiri dari kurikulum yang ada kaitannya dengan mata pelajaran atau dalam proses kegiatan belajar mengajar yang disebut intrakurikuler dan kurikulum yang tidak ada kaitannya dengan mata pelajaran dan dilakukan secara rutin yang disebut dengan ekstrakurikuler.

Proses pembelajaran yang dikembangkan mengaitkan mata pelajaran dengan nilai imtaq. Dengan cara pembelajaran yang demikian, keyakinan dan pemahaman peserta didik terhadap materi yang sedang diajarkan semakin meningkat, yang akhirnya dapat meningkatkan keimanan dan ketaqwaan mereka.

Untuk mengetahui komposisi jumlah mata pelajaran dan jam pelajaran setiap pekannya, penulis menggambarkannya dalam bentuk tabel berikut.

Tabel 1

Struktur Kurikulum SMA Islam Al Azhar 5 Kota Cirebon

\begin{tabular}{|c|c|c|c|c|c|}
\hline \multirow{2}{*}{ No. } & \multirow{2}{*}{ MATA PELAJARAN } & \multicolumn{3}{|c|}{ JUMLAH JAM PELAJARAN } \\
\cline { 3 - 6 } & & KLS I & KLS II & III IPA & III IPS \\
\hline 1 & PENDIDIKAN AGAM & & & & \\
\hline & a. Alquran & 2 & 2 & 2 & 2 \\
\hline
\end{tabular}

${ }^{30}$ Nasrun Harahap, dkk, Penelitian dan Penilaian Pendidikan. (Bandung :Sinar Baru. 1983), 97 


\begin{tabular}{|c|c|c|c|c|c|}
\hline & b. Pendidikan Agama Islam & 3 & 3 & 3 & 3 \\
\hline & c. Bahasa Arab & 2 & 2 & 2 & 2 \\
\hline 2 & PPKN & 2 & 2 & 2 & 2 \\
\hline 3 & $\begin{array}{l}\text { BAHASA DAN SASTRA } \\
\text { INDONESIA }\end{array}$ & 5 & 5 & 3 & 3 \\
\hline 4 & SEJARAH NASIONAL/UMUM & 2 & 2 & 2 & 2 \\
\hline 5 & BAHASA INGGRIS & 4 & 4 & 5 & 6 \\
\hline 6 & $\begin{array}{l}\text { PENDIDIKAN JASMANI DAN } \\
\text { KESEHATAN }\end{array}$ & 2 & 2 & - & - \\
\hline 7 & MATEMATIKA & 7 & 7 & 9 & 3 \\
\hline 8 & ILMU PENGETAHUAN ALAM & & & & \\
\hline & a. Fisika & 6 & 6 & 8 & - \\
\hline & b. Biologi & 4 & 4 & 8 & - \\
\hline & c. Kimia & 4 & 4 & 7 & - \\
\hline 9 & $\begin{array}{l}\text { ILMU PENGETAHUAN } \\
\text { SOSIAL }\end{array}$ & & & & \\
\hline & a. Ekonomi/Akuntansi & 3 & 3 & - & 10 \\
\hline & b. Geografi & - & 2 & - & 6 \\
\hline & c. Sosiologi & - & - & - & 6 \\
\hline & d. Antropologi & - & - & - & 6 \\
\hline & e. Tata Negara & - & - & - & 6 \\
\hline 10 & PENDIDIKAN KESENIAN & 2 & - & - & - \\
\hline 11 & BIMBINGAN KONSELING & 1 & 1 & - & - \\
\hline & JUMLAH & 51 & 51 & 51 & 51 \\
\hline
\end{tabular}

2. Internalisasi Nilai-nilai Imtaq dalam pembentukan Kepribadian Siswa SMA Islam Al Azhar 5 Kota Cirebon Melalui Kegiatan Intrakurikuler Upaya guru SMA Islam Al Azhar 5 Kota Cirebon dalam menginternalisasikan nilai-nilai imtaq atau kegiatan di dalam kelas pada saat proses kegiatan belajar mengajar, terdiri atas; (a) berdoa (ikrar) sebelum dan sesudah belajar; tadarus Alquran; (c) mengaitkan materi pelajaran dengan imtaq. 
Berdasarkan observasi partisipatif, wawancara dan angket, maka diperoleh data keseluuhan tentang respon siswa terhadap upaya guru dalam menginternalisasikan nilai-nilai iman dan taqwa (imtaq) bagi pembentukan kepribadian siswa melalui kegiatan intrakurikuler dapat dilihat pada tabel rekapitulasi rata-rata keseluruhan. Adapun data tersebut sebagai berikut:

Tabel 2

Rekapitulasi Tanggapan responden atas Usaha Guru dalam Menginternalisasikan Nilai-Nilai Imtaq melalui kegiatan Intrakurikuler

\begin{tabular}{|c|l|c|c|c|c|}
\hline \multirow{2}{*}{ No } & \multicolumn{1}{|c|}{ INDIKATOR } & \multicolumn{3}{c|}{ JAWABAN } & \multirow{2}{*}{$\%$} \\
\cline { 3 - 5 } & & $\mathrm{A}$ & $\mathrm{B}$ & $\mathrm{C}$ & \\
\hline 1 & Berdoa sebelum dan sesudah belajar & $75 \%$ & $25 \%$ & 0 & 100 \\
\hline \multirow{2}{*}{2} & $\begin{array}{l}\text { Tadarus Alquran 15 menit pada jam } \\
\text { pertama sebelum kegiatan belajar } \\
\begin{array}{l}\text { mengajar di kelas } \\
3\end{array}\end{array}$ & $81,7 \%$ & $18,3 \%$ & 0 & 100 \\
& $\begin{array}{l}\text { Mengaitkan materi pelajaran dengan } \\
\text { muatan imtaq }\end{array}$ & $90 \%$ & $10 \%$ & 0 & 100 \\
\hline & Rata-Rata & $82,2 \%$ & $17,8 \%$ & 0 & 100 \\
\hline
\end{tabular}

Dari data tersebut di atas dapat dijelaskan bahwa diperoleh $75 \%$ siswa yang selalu berdoa sebelum dan sesudah belajar, ada $25 \%$ siswa yang kadang-kadang berdoa sebelum dan sesudah belajar, dan $0 \%$ siswa yang tidak berdoa sebelum dan sesudah belajar. Berdasarkan perolehan prosentase respon siswa terhadap kegiatan berdoa sebelum dan sesudah belajar dapat dikategorikan baik bagi usaha guru dalam menginternalisasikan nilai-nilai imtaq melalui kegiatan tersebut dalam pembentukan kepribadian bagi siswa SMA Islam Al Azhar 5 Kota Cirebon.

Walaupun demikian hendaknya ditingkatkan lagi usaha tersebut karena masih ada $25 \%$ siswa yang belum konsisten melaksanakan kegiatan berdoa sebelum dan sesudah belajar. Dengan usaha maksimal akan kepedulian guru terhadap aktivitas berdoa bagi siswanya mudah-mudahan siswa akan menyadari pentingnya berdoa dan mau melaksanakannya dengan penuh harap. 
Berdasarkan tabel di atas juga diperoleh $81,7 \%$ siswa yang selalu melaksanakan kegiatan tadarus Alquran 15 menit jam pertama sebelum kegiatan belajar mengajar. Adapun siswa yang kadang-kadang melaksanakan kegiatan tadarus Alquran tersebut berjumlah 18,3\%. Dari perolehan data prosentase tersebut maka usaha guru dalam menginternalisasikan nilai-nilai imtaq melalui kegiatan tadarus alquran 15 menit sebelum kegiatan belajar mengajar dalam pembentukan kepribadian bagi siswa SMA Islam Al Azhar 5 Kota Cirebon dapat dikategorikan baik sekali. Walaupun demikian bukan berarti guru harus berhenti dari upaya-upaya untuk mempertahankan dan meningkatkan keberhasilan itu. Lagi pula keberhasilan itu bersifat sementara dalam artian tanpa kerja keras untuk mempertahankan dan meningkatkan prosentase itu hal itu bisa jadi prosentase keberhasilan itu akan menurun. Ada 18,3\% siswa yang masih membutuhkan perhatian dari guru dalam aktivitas tadarus Alquran 15 menit pada jam pertama sebelum kegiatan belajar di kelas.

Berdasarkan tabel di atas juga dapat dijelaskan bahwa diperoleh 90\% siswa yang memahami dan meyakini ilmu yang dipelajarinya di dalam kelas dapat menambah keimanan dan ketaqwaan kepada Allah SWT. dan ada 10\% siswa yang menyatakan kadang-kadang dalam memahami dan meyakini ilmu yang didapatinya di kelas dapat meningkatkan keimanan dan ketaqwaan kepada Allah SWT. Dari perolehan berdasarkan prosentase tersebut maka usaha guru dalam menginternalisasikan nilainilai imtaq melalui kegiatan mengaitkan materi pelajaran dengan muatan imtaq bagi siswa SMA Islam Al Azhar 5 Kota Cirebon dapat dikategorikan baik sekali. Walaupun demikian masih ada $10 \%$ siswa yang perlu diperhatikan guru dalam aktivitas mangaitkan materi pelajaran dengan muatan imtaq. Hal ini dapat diduga keras bahwa ada dua hal yang menyebabkanyaitu: keterbatasan guru dalam mengaitkan materi pelajaran dengan muatan imtaq atau bisa juga siswa kurang memperhatikan.

Berdasarkan tabel rekapitulasi di atas dapat dijelaskan bahwa diperoleh 82,2\% siswa yang merespon upaya guru dalam menginternalisasikan nilai-nilai imtaq melalui 
kegiatan intrakurikuler. Berdasarkan prolehan rata-rata prosentase dari respon siswa tersebut maka dapat dikategorikan baik sekali. Walaupun demikian tentunya usahausaha guru untuk mempertahankan dan meningkatkan seharusnya terus dilakukan karena masih ada 17,8\% siswa yang masih belum stabil atau tidak konsisten dalam mengikuti kegiatan tersebut.

E. Simpulan dan Rekomendasi

1. Simpulan

a. Usaha guru dalam menginternalisasikan nilai-nilai iman dan taqwa dalam pempentukan kepribadian siswa di SMA Islam Al Azhar 5 Kota Cirebon melalui kegiatan intrakurikuler yang meliputi kegiatan berdoa sebelum dan sesudah belajar, tadarus Alquran 15 menit jam pertama sebelum kegiatan belajar mengajar dan mengaitkan materi pelajaran dengan muatan iman dan taqwa (imtaq) dikategorikan sangat baik berdasarkan data respon siswa diperolah $82,2 \%$.

b. Kendala yang dihadapi oleh guru dalam menginternalisasikan nilai-nilai iman dan taqwa dalam pembentukan kepribadian siswa di SMA Islam Al Azhar 5 Kota Cirebon melalui kegiatan intrakurikuler diantaranya kurangnya pemahaman beberapa guru mata pelajaran non pendidikan agama Islam dalam mengaitkan mata pelajaran dengan muatan iman dan taqwa.

2. Rekomendasi

a. Upaya sekolah dalam membentuk dan membeina kepribadian siswa hendaknya dilakukan dalam berbagai cara salah satunya adalah menginternalisasikan nilainilai iman dan taqwa dalam pembentukan kepribadian melalui kegiatan intrakurikuler. Aktivitas ini sangat bermanfaat bagi para siswa pada saat dibina dan masa yang akan datang dalam menjalani hidup dan kehidupan mereka. Bekal nilai-nilai inilah yang dijadikan pedoman bagi mereka dalam bertutur kata dan bertindak sehingga mereka benar-benar bermanfaat bagi dirinya sendiri, orang tua, masyarakat, bangsa dan agama.

b. Penelitian ini hanya sebatas internalisasi nilai-nilai iman dan taqwa dalam pembentukan kepribadian melalui kegiatan intrakurikuler. Masih perlu 
penelitian lanjutan melalui kegiatan-kegiatan lain seperti kegiatan ekstrakurikuler, kegiatan program keagamaan dan kegiatan lainnya.

\section{DAFTAR PUSTAKA}

Ahmadi, Abu. .Psikologi Sosial .Jakarta:Cipta Rineka,Cetakan I.1991

Al-Djamaly, M. Fadhil..Ilmu Pendidikan Islam, Terjemahan;M. Arifin. Jakarta: Bumi Aksara 1991

Anshari,E.S. Ilmu, Filsafat dan Agama.. Surabaya:PT. Bina Ilmu 1987.

Badri, Malik B.,. Dilema Psikolog Muslim, Terjemahan; Siti Zaenab Lukfiati.. Jakarta: Pustaka Firdaus 1986

Darazat,Zakiyah..Pendidikan Agama dalam Pembinaan Mental. Jakarta :Bulan Bintang. 1970 Depdiknas,.Kamus Besar Bahasa Indonesia. Jakarta: Balai Pustaka. 2001

Fraenkel, R.J.. How to Teach about Values: An analytic Approach. Bey Jersey: Printice Hall Inc. Englewood Cliff. 1977

Gulo,Dali..Kamus Pschology.Bandung :Tonis. 1982

Harahap, Nasrun, at al..Penelitian dan Penilaian Pendidikan. Bandung :Sinar Baru. 1983

Hayan,Abu..Tafsir al Bahr al Muhith, Jilid I. Mesir : Dar al Fikr. 1978

Jalaluddin..Kepribadian Muslim; Palembang :Diktat. 1964

Loewald,H..Internalization, Separation, Mourning and the Superego ; Pschoanalitic Quarterly.journal of the American Psychoanalytic Association. 1962

Madjid,Nurcholis..Islam Doktrin dan Peradaban. Jakarta:Yayasan Wakaf Paramadina. 1992

Ma'luf,Luis, Munjid Fi al Lughah wa al-A'lam.. Libanon:al Maktabah al Syarqiyah.Beirut. 1986

Mahalli, Ahmad Mudjab..Membangun Pribadi Muslim. Yogyakarta: Menara kudus. 2002

Maisyanah Maisyanah;Lilis Inayati, Edukasia:Jurnal Penelitian Pendidikan Islam, Vol 13, Iss 2 (2019), STAIN Kudus, 2019

Meissner,ww..Internalization in Psychoanalysis. New York :International. Inc. 1981

Muhaimin, Paradigma Pendidikan Islam, Bandung:PT. Remaja Rosdakarya, 2001 Wacana Pengembangan Pendidikan Islam. Surabaya: Pustaka Pelajar. 2003

Mulyana, Rohmat.. Mengartikulasikan Pendidikan Nilai. Bandung:Alfabeta. 2004

Musa Alfadhil, Jurnal Mudarrisuna: Media Kajian Pendidikan Agama Islam, Vol 9, Iss 1, Pp 26-35,(2019), UIN Ar Raniri, 2019 
Nuhyal Ulia; Yunita Sari;Mohamad Hariyono, Jurnal Studi Guru dan Pembelajaran, Vol 3, Iss 1, Pp 1-10 (2020); Universitas Cokroaminoto Palopo, 2020

Ramayulis..Ilmu Pendidikan Islam. Jakarta:Kalam Mulia. 2004

Shihab, Muhammad Quraish..Tafsir al-Amanah. Jakarta:Pustaka Kartini. 1992

Soekanto, M.N.Nafsiologi. Jakarta :Integsita Proses. 1985

Syah, Wahyudin..Pengantar Penelitian Ilmiah. Bandung:Tarsito. 1989

Ulwan, Abdullah Nasih,.Tarbiyah Ruhiyah: Petunjuk Praktis Mencapai Derajat Taqwa. Jakarta:Gema Insani Press.2001 